\title{
The Contribution of Forest Extraction to Income Diversification and Poverty Alleviation for Indonesian Smallholder Cattle Breeders
}

\author{
Eko Nugroho $^{1,2}$ (D) Rico Ihle $^{2}$ (D) $\cdot$ Wim Heijman ${ }^{2,3}$ (D) Simon J. Oosting ${ }^{4}$ (iD
}

Accepted: 31 January 2022 / Published online: 1 March 2022

(c) The Author(s) 2022

\begin{abstract}
Smallholder farmers in developing countries often lack resources. They rely mostly on extensive production approaches, such as cattle keeping and resort more to extracting forest resources at no charge. Our objective is to assess the relationship between the diversification of income sources, poverty and livelihood capital for smallholder farm households which combine cattle farming with forest extraction. We collected 600 surveys from Indonesian farmers specialized along the cattle rearing supply chain (464 breeders, 66 feeders and 70 mixed breeder-feeders). We found no correlation between poverty and income diversification. Cattle breeders have been found to rely most on forest resources. Distance to cropland and forest correlated positively, whereas their education level correlated negatively with income diversification. Feeders who were owning other livestock, were a member of a forest user group and owned some modest capital like a motorbike showed increased income diversification. Crops are the most important source of income for farmers, whereas cattle keeping and forest extraction play a role in income diversification. Increasing ecological pressure caused by forest extraction due to expanding cattle production could be best avoided by extending those parts of the cattle sector that use forest resources in a sustainable manner, for instance, through silvopastural systems or agroforestry so that incomes of poor farmers get more diversified and, therefore stabilized.
\end{abstract}

Keywords Poverty $\cdot$ Smallholders $\cdot$ Livelihood $\cdot$ Beef production $\cdot$ Timber $\cdot$ Nontimber

Eko Nugroho

eko_nug@ub.ac.id

Extended author information available on the last page of the article 


\section{Introduction}

Income diversification is vital for coping with poverty because it enables the poor to spread risks and improve their resilience against shocks (Ansah et al. 2021; World Bank 2008), and it can contribute to increasing the resource endowment of the poor. The World Bank (2008) highlights that farmers in countries, such as Tanzania, Uganda and Nigeria who diversified their farming activities by growing food crops in combination with cash crops (e.g. vegetables, fruits, and vanilla) as well as raising livestock were the most successful to move out of poverty compared to non-diversified farmers.

This phenomenon also holds for South-East Asia since also there, households pursuing multiple income-generating activities earned higher total incomes than those with a single source income. This was observed in Vietnam, where smallholders benefited from income diversification through non-farm employment and engagement in high-value crop production, such as fruits or tea (Minot et al. 2006). In addition, rural households in Cambodia that diversified their activities through livestock keeping, collection of non-timber forest products (NTFP; examples are fuelwood, forest grass as animal fodder, mushrooms, herbs, and game) and crop production had significantly higher incomes than subsistence farmers (Jiao et al. 2017).

The World Bank (2018) revealed that Indonesia had 28 million poor people in 2018 , confirming that poverty remains a prominent issue in the country. Badan Pusat Statistik (BPS 2017) reported that 4.6 million poor people (about one-fifth of Indonesia's poor) live in East Java. Two-thirds of these poor reside in rural areas and primarily rely on agriculture as the major source of their income (BPS 2017). Moreover, about 1.3 million ha (28\%) of the land in the province of East Java consists of forest, of which $51 \%$ is teak forest (BPS 2017). East Java also hosts about one-third of Indonesia's 16.5 million cattle, making the province the largest cattle production area of the country (DJPKH 2017). The roles of forest products and small-scale cattle production as elements for income diversification for farming households has barely received attention so far. The literature is limited on income diversification in the context of South-East Asia in particular. To the best of our knowledge, Minot et al. (2006) is the only publication highlighting that engagement in non-farm employment and a higher-value crop production as a successful income diversification strategy. In the present paper, we address this knowledge gap by studying income diversification of farmers combining cattle farming and forest extraction. Moreover, we examined the association between farmers' income diversification and poverty and livelihood capital (Ellis 2000). Livelihood capital refers to resources owned by farmers and are often classified into five categories: human, physical, financial, natural and social capital (Ellis 2000). We focus on East Java because cattle production, teak forest extraction and poverty are very prevalent in this province hosting about one third to the Indonesian cattle population, half of its area being covered by teak forest and being the home of about one fifth of Indonesia's poor. The core interest of our analysis of the cattle-forests-poverty nexus lies on studying the potential interdependencies 
between teak forest and cattle keeping as income diversification strategies (Angelsen and Wunder 2003; Caviglia-Harris and Sills 2005; Pellegrini and Tasciotti 2014).

\section{Materials and Methods}

\section{Research Area and Farmers}

The present study was conducted in the Bojonegoro district in East Java, Indonesia from July to December 2017. In 2016, the cattle population in this district was about 200,000 heads and it is considered one of the most important cattle production areas of East Java (BPSJ 2017). There are three dominant farming systems (FSs) with beef cattle distinguishable in the study area: breeders, feeders, and mixed breederfeeders. Breeders are smallholders producing calves mainly at extensive farms using low input-low output strategies. Such breeders have a herd of reproductive animals to produce male calves for rearing, whereas female calves are used for replacement of reproductive cows. Feeders are smallholders engaging in rearing young bulls for about 1 year from approximately $250-350 \mathrm{~kg}$ live weight employing a moderate level of inputs, such as concentrates. After this rearing the bulls are sold to feedlots for the final fattening stage. Breeder-feeders are cattle farmers combining the breeder and feeder activities.

In all FSs, there were farmers with and without forest extraction. Farmers with forest extraction engage in collecting forest products to support their livelihoods, such as timber and NTFPs. Farmers without forest extraction are farmers who do not engage in the collection of timber and NTFPs.

\section{Conceptual Framework}

We applied the sustainable livelihood approach developed by the UK Department for International Development (DFID 1999) to empirically analyse the interactions between household capital and their roles for diversifying income to attain livelihood outcomes. However, external perturbations and institutional frameworks may affect the households' abilities to achieve those outcomes as illustrated in Fig. 1.

As the goal of the analysis was to analyse households' choices for income diversification, we measured their incomes earned from multiple sources, such as crops, cattle, other livestock, timber and NTFPs, paid agricultural employment and nonagricultural employment. For example, a household with a small plot of agricultural land may raise cattle or work as labourers for other farmers to stabilize income from crop production (see $a$ in Fig. 1).

Ellis (2000) characterizes a livelihood as consisting of three elements: capabilities, capital and activities required for achieving a decent living standards. Figure 1 shows that household capital may consist of natural, physical, human, financial or social capital (Babulo et al. 2008). We considered several of those in the analysis. Indicators for natural capital are households' ownership of agricultural land and 


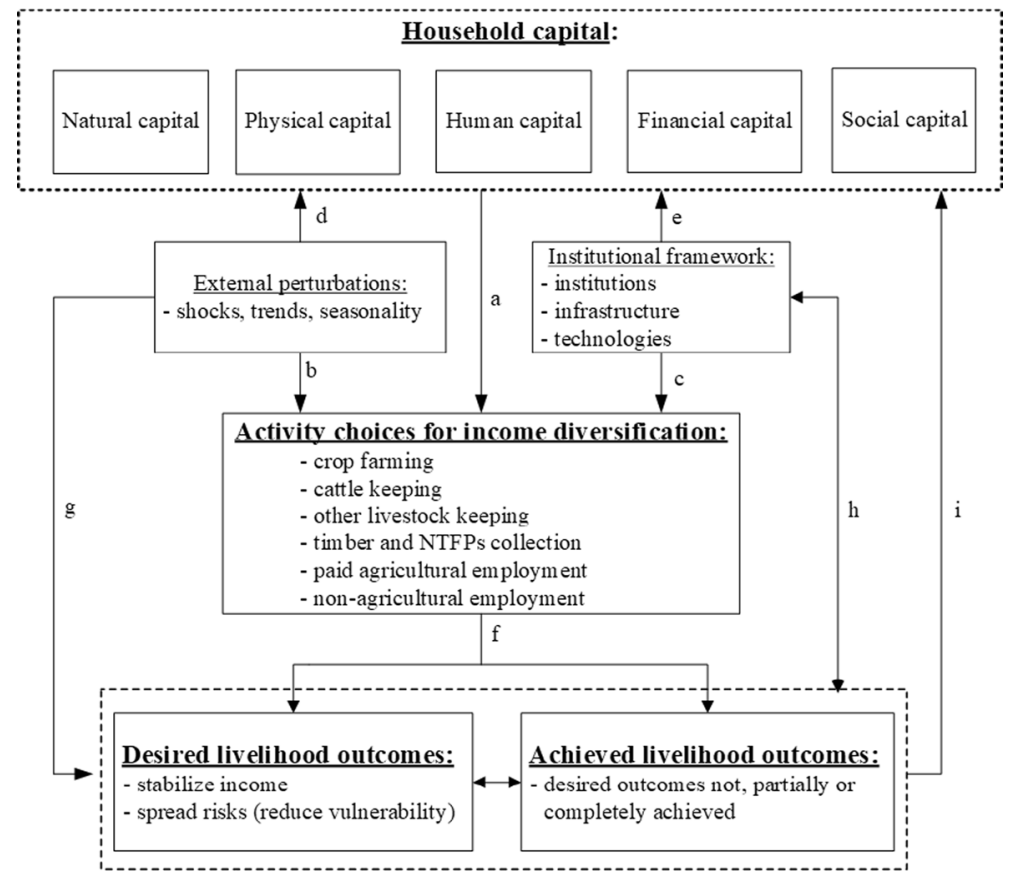

Fig. 1 Conceptual framework for sustainable livelihood. Source: adapted from Babulo et al. (2008)

the size, the location, and the quality of agricultural land. Forest ownership is not a natural capital for the households because it is owned by the state. None of the farmers surveyed reported to own private forest because all teak forests are owned and managed by the state-owned forest company, Perhutani. Extracting forest resources helps farm households to diversify income and comes with risks as they may choose to legally or illegally log teak trees or fetch other forest resources for subsistence use or marketing. Hence, making use of these forest resources may generate additional revenues for households or help them to avoid expenses, e.g., for cattle forage, fuelwood or construction wood. Indicators for physical capital are households' ownership of transportation vehicles, such as bikes, motor bikes, or cars. Human capital are quantified as age and level of education of the household head and household size. Indicators for financial capital are households' ownership of cattle and other livestock, and households' access to credit and savings. Lastly, the indicator for social capital is the households' membership in a local forest user group.

A household chooses activities to attain its livelihood outcomes, such as stabilizing income or spreading risk. However, external factors (arrow $g$ ) and the given institutional framework (arrow $h$ ) may cause households to end up with actual outcomes differing from desired ones (arrow $f$ ). These outcomes, in turn, can influence the household capital, for instance, through investments (arrow $i$ ).

We separate desired and actual income in the livelihood outcomes shown in Fig. 1 because the smallholders' mostly nature-based livelihood activities are occasionally disturbed by unexpected events. Households reported to have different kinds and 
amounts of capital available for coping with different kinds of external shocks, such as price shocks or other unexpected economic challenges, diseases, pests or extreme weather. These shocks may lead to a lower crop yield and lower revenues resulting in households that may end up with actual income which may be lower than the desired income level and even find their food security challenged (for details see e.g., Ansah et al. (2021)).

External perturbations, such as shocks, trends and seasonality can either directly impact activity choices (arrow $b$ in Fig. 1) or indirectly via impacting household capital (arrow $d$ ). For example, natural calamities, such as floods and landslides can destroy the available land resources. Weather shocks may lead to crop failures. Forest fires may destroy forest resources. Similarly, the institutional framework the household faces, such as existing institutions, infrastructural conditions and available technologies, may directly influence households' decisions to select an activity (arrow $c$ ) or indirectly affect its capital (arrow $e$ ). For example, the location determines the distance and the effort for traveling to destinations crucial for the household livelihoods, such as fields, grazing grounds, forests or markets. In addition, being a member of a forest user group may improve the portfolio and the magnitude of capital accessible to the household or the set of feasible activities from which it may choose.

\section{Data Collection}

In order to representatively cover all FSs, we collected data in three farming system regions of the Bojonegoro district which as defined by the district government. In each region, we selected one sub-district with high cattle density and one with low cattle density yielding six sub-districts in total. Due to the variation in numbers of farmers between sub-districts, the sample sizes in the sub-districts were proportional to the total number of farmers in that sub-district. Hence, four to 15 villages per subdistricts were selected based on accessibility and concentration of cattle farmers. An equal number of sample farmers per village was taken using the snowball technique (regardless of the size of the village), starting with a farmer nominated by the village officer. As smallholder farmers are most vulnerable to income shocks and poverty threats, we focus on them and selected cattle breeders who were operating maximum 1 ha of agricultural land (BPS 2016) and had been keeping cattle for at least one year. This applied to approximately $90 \%$ of the farmers in the study area. After obtaining the research approval from the government of Bojonegoro, surveys were conducted by individual interviews with the selected farmers using questionnaires.

\section{Data Analysis}

As the first step of the analysis, we studied the characteristics of farming households by comparing the FSs regarding capital endowment, geographical location, income portfolios and income diversity index. For this aim, we compared the means of such characteristics using analysis of variance (ANOVA) followed by the post-hoc Tukey test. 
In line with Ellis (2000), we analysed the income portfolios of farmers by calculating their income from six potential income sources: crop farming, cattle farming, keeping other livestock, forest extraction, paid agricultural labour, and non-farm employment. Crop income is the financial value of all crop products over a year grown by a farmer less the costs associated with crop production paid by the farmers to third parties. Cattle income is total money earned from selling cattle minus all costs of cattle production in the last 12 months. Other livestock income is total money earned from selling livestock, such as goats, sheep, and chickens over a year minus all costs of livestock production. Forest income is the total financial value of all forest products, such as charcoal, fuelwood, teak branches, teak roots, and teak leaves over a year valued at local market prices. Paid agricultural labour income is the income earned from hiring out labour for daily wages or seasonal work on other farms during the past 12 months. Non-farm income is the income earned from non-agricultural employments, such as being a civil servant, self-employment (e.g., a motorbike-taxi driver or the owner of a small shop) as well as remittances during the past 12 months.

As the third step of the analysis, we measured farmers' income diversification using the inverse of Herfindahl-Hirschman index $\mathrm{Y}_{\mathrm{i}}$ as it has a straightforward interpretation and has been used to study income diversification of rural households in many contexts (Jiang and Han 2018; Kassie 2017; Tesfaye et al. 2011). Farmers having a higher index have more diversified income sources than those with a lower index. The income diversification index $Y_{i}$ was calculated for each farmer $i$ using all relevant income sources:

$$
\mathrm{Y}_{\mathrm{i}}=\frac{1}{\sum_{\mathrm{m}=1}^{\mathrm{M}} \mathrm{P}_{\mathrm{m}}^{2}}
$$

where $\mathrm{P}_{\mathrm{m}}$ is the proportion of income source $\mathrm{m}$ contributing to total income. $\mathrm{M}$ is the total number of income sources contributing to the livelihood of farmer i. A farmer not diversifying at all, having $\mathrm{P}_{\mathrm{m}}=1$ and $\mathrm{M}=1$, will have an index of $\mathrm{Y}_{\mathrm{i}}=1$, a farmer having $M=4$ sources with each of them having a share of exactly $P_{m}=0.25$, will have an index of $Y_{i}=4$. But if two have a share of 0.25 , one of 0.4 and the fourth of 0.1 , then the diversification index of this farmer will only amount to 3.39.

Moreover, we assessed the relation between income diversification and poverty as Abdulai and CroleRees (2001) found that poorer households diversify their sources of income more to minimize risk. For this aim, we measured the correlation between the income diversification index of farmer $\mathrm{i}\left(\mathrm{Y}_{\mathrm{i}}\right)$ and the poverty index of farmer $\mathrm{i}$ $\left(\mathrm{PI}_{\mathrm{i}}\right)$. The poverty index $\mathrm{PI}_{\mathrm{i}}$ was calculated by dividing the total number of poverty indicators a household reported in the survey (see Table 1) by the official threshold number for being poor of having at least five of these indicators set by the Indonesian Ministry of Social Affairs. MoSA (2012) identified 14 different poverty indicators as listed in Table 1 and farmers were classified very poor if scoring on more than five poverty indicators and poor to a limited extent if they have one to five poverty indicators.

We also assessed the relation between forest income, share of forest income and poverty as literature shows that poor household living in or near the forest earn 
Table 1 Poverty indicators identified by the ministry of social affairs in Indonesia. Source: MoSA (2012)

\begin{tabular}{ll}
\hline No & Poverty indicators \\
\hline 1 & Households live in a small house which is $<8 \mathrm{~m}^{2}$ per person \\
2 & Households' floor is made of land/dirt/earth or low quality wood or bamboo \\
3 & Households' walls are made of low quality wood or board \\
4 & Households' house does not have toilet facility \\
5 & Households' house does not connect to electricity \\
6 & Source of drinking water is not protected, such as a well or river \\
7 & Households use fuelwood, charcoal or kerosene as fuel for cooking \\
8 & Households consume meat or milk once per week or less \\
9 & Households purchase new clothes once a year or less \\
10 & The frequency of eating of households less than 2 times a day \\
11 & Households are not able to pay health costs for non-serious illness \\
12 & Household heads work as farmer or farm labourer with land sizes $<0.5$ ha \\
13 & Household heads' education level is primary school or less \\
14 & Households do not have major assets, such as a motorbike \\
\hline
\end{tabular}

income from forest extraction (Senadza 2014). For this aim, we measured the correlation between the poverty index of farmer $\mathrm{i}\left(\mathrm{PI}_{\mathrm{i}}\right)$ and forest income and share of forest income in total income.

Lastly, following Ellis (2000) we investigated socio-economic factors associated with income diversification. ${ }^{1}$ We regressed the income diversification index $Y_{i}$ of farmer $\mathrm{i}$ on the exlanatory variables $\mathrm{x}_{1}$ to $\mathrm{x}_{14}$ which are the relevant livelihood capital and geographical locations of farmer $i$ using ordinary least squares (OLS) regression model (Verbeek 2012):

$$
\mathrm{Y}_{\mathrm{i}}=\beta_{0}+\beta_{1} \mathrm{x}_{\mathrm{i} 1}+\ldots+\beta_{14} \mathrm{x}_{\mathrm{i} 14}+\varepsilon_{\mathrm{i}}
$$

where $\beta_{0}$ is the intercept of the model, $\beta_{1}$ to $\beta_{14}$ are the coefficients of the partial influences of the explanatory variables $\mathrm{x}_{1}$ to $\mathrm{x}_{14}$ and $\varepsilon_{\mathrm{i}}$ is the error term.

Table 2 summarizes expected impacts of the livelihood capital types and geographical location variables on income diversification. We expected that income diversification associates positively with household size, access to credit and saving, poverty, ownership of motorbike, membership of a forest user group and distance to the nearest market. We expected that income diversification associates negatively with age, education, farm size, number of cattle owned by a household, and distance to cropland and forest. Whereas the association between the number of other livestock on income diversification is unknown.

For statistical analysis, first, we compared the mean values of capital endowment, location of farming systems, total annual income, share of income sources in total income, income diversification index by farming systems. Second, we

\footnotetext{
${ }^{1}$ Correlations among the explanatory variables used in the regression model has been checked to be of very low magnitude.
} 


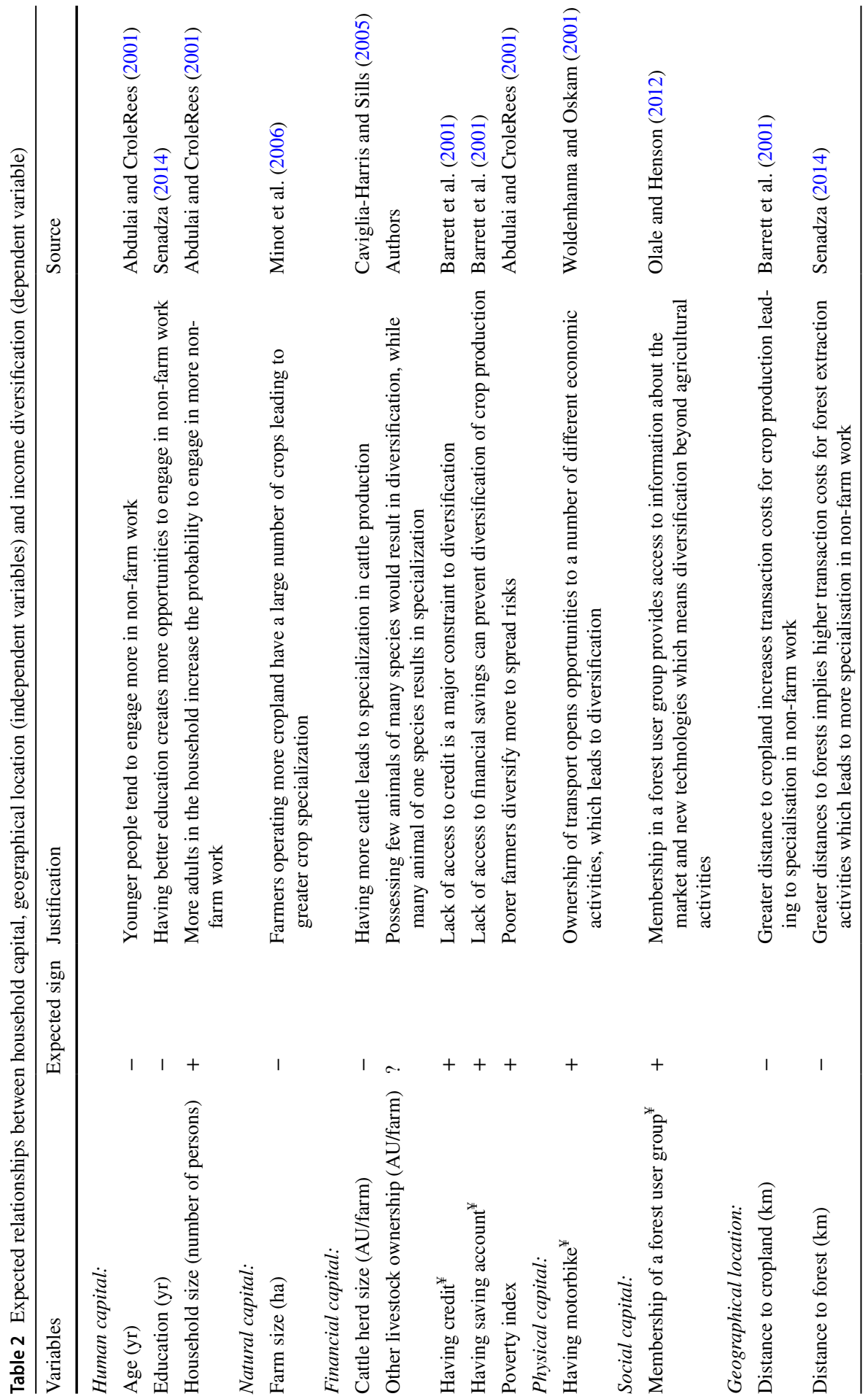




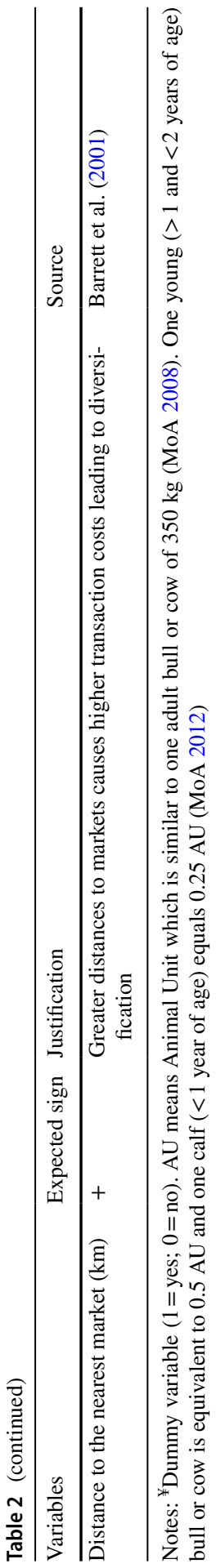


Table 3 Distribution of farmers by different farming systems

\begin{tabular}{|c|c|c|c|c|c|c|}
\hline \multirow[t]{2}{*}{ Farming systems } & \multicolumn{2}{|c|}{$\begin{array}{l}\text { With forest } \\
\text { extraction }\end{array}$} & \multicolumn{2}{|c|}{$\begin{array}{l}\text { Without } \\
\text { forest } \\
\text { extraction }\end{array}$} & \multicolumn{2}{|c|}{ Total } \\
\hline & $\mathrm{n}$ & $\%$ & $\mathrm{n}$ & $\%$ & $\mathrm{n}$ & $\%$ \\
\hline Breeders & 212 & 35.3 & 252 & 42.0 & 464 & 77.3 \\
\hline Feeders & 16 & 2.7 & 50 & 8.3 & 66 & 11.0 \\
\hline Mixed breeder-feeders & 29 & 4.8 & 41 & 6.9 & 70 & 11.7 \\
\hline Total & 257 & 42.8 & 343 & 57.2 & 600 & 100.0 \\
\hline
\end{tabular}

analyzed the correlation between the poverty index and forest income, the poverty index and share of forest income in total household income, and the poverty index and income diversification index. Third, we regressed income diversification on capital endowment and geographical location for each farming system separately. Differences mentioned are significant at the 5\% level unless otherwise stated.

\section{Results}

\section{Characteristics of Farmers Across Different Farming Systems}

Most cattle farmers (77.3\%) were breeders (Table 3). Of all cattle farmers $42.8 \%$ participated in forest extraction without differences among FSs.

No differences were observed regarding livelihood capital types between FSs, except that mixed breeder-feeders owned more cattle than breeders, who in turn owned more cattle than feeders (Table 4). Moreover, both breeders and feeders were significantly poorer than mixed breeder-feeders.

\section{Farmers' Income Portfolios and Income Diversification Index}

We found no differences between FSs in terms of total income (Table 5). However, breeders had a significantly lower cattle income share, and a higher forest income share compared to feeders. Moreover, breeders had a significantly lower other livestock income share than mixed breeder-feeder farmers. No differences were found among FSs regarding income shares from crop farming, non-farm employment and paid agricultural jobs and regarding income diversification index.

Figure 2 show no association between forest income, share of forest income, income diversification and poverty indicated by low correlation coefficients and high p-values, all of which are greater than 0.05 . 
Table 4 Mean comparison of capital endowment and location of farming systems (between brackets: s.e.)

Breeders $(n=464) \quad$ Feeders $(n=66) \quad$ Mixed breeder-
feeders $(n=70)$

\begin{tabular}{|c|c|c|c|}
\hline \multicolumn{4}{|l|}{ Human capital } \\
\hline Age $(y r)$ & $51.0(0.51)$ & $49.3(1.19)$ & $51.0(1.13)$ \\
\hline Education (yr) & $5.4(0.16)$ & $6.0(0.43)$ & $5.8(0.43)$ \\
\hline Household size (number of persons) & $3.9(0.06)$ & $4.0(0.14)$ & $4.1(0.16)$ \\
\hline \multicolumn{4}{|l|}{ Natural capital } \\
\hline Farm size (ha) & $0.2(0.01)$ & $0.2(0.03)$ & $0.2(0.03)$ \\
\hline \multicolumn{4}{|l|}{ Financial capital } \\
\hline Cattle herd size (AU/farm) & $1.3(0.03)^{\mathrm{b}}$ & $0.7(0.06)^{\mathrm{c}}$ & $1.8(0.13)^{\mathrm{a}}$ \\
\hline Other livestock ownership (AU/farm) & $0.1(0.01)$ & $0.1(0.02)$ & $0.1(0.03)$ \\
\hline Having credit ${ }^{¥}$ & $0.17(0.02)$ & $0.18(0.05)$ & $0.11(0.04)$ \\
\hline Having saving account ${ }^{¥}$ & $0.22(0.02)$ & $0.24(0.05)$ & $0.23(0.05)$ \\
\hline Poverty index & $0.93(0.01)^{\mathrm{a}}$ & $1.02(0.03)^{\mathrm{a}}$ & $0.79(0.03)^{\mathrm{b}}$ \\
\hline \multicolumn{4}{|l|}{ Physical capital } \\
\hline Having motorbike ${ }^{¥}$ & $0.94(0.01)$ & $0.94(0.03)$ & $0.93(0.03)$ \\
\hline \multicolumn{4}{|l|}{ Social capital } \\
\hline Membership of a forest user group ${ }^{¥}$ & $0.11(0.01)$ & $0.06(0.03)$ & $0.10(0.04)$ \\
\hline \multicolumn{4}{|l|}{ Geographical location } \\
\hline Distance to cropland (km) & $0.6(0.03)$ & $0.5(0.07)$ & $0.6(0.08)$ \\
\hline Distance to forest $(\mathrm{km})$ & $0.4(0.03)$ & $0.2(0.07)$ & $0.2(0.05)$ \\
\hline Distance to the nearest market $(\mathrm{km})$ & $1.4(0.11)$ & $1.7(0.34)$ & $1.4(0.31)$ \\
\hline
\end{tabular}

Notes: ${ }^{\ddagger}$ Dummy variable $(1=$ yes; $0=$ no)

${ }^{a-c}$ Means within a row with different superscripts differ significantly $(p<0.05)$ between farming systems (according to the post hoc test described in "Materials and Methods" section). AU means Animal Unit which is similar to one adult bull or cow of $350 \mathrm{~kg}$ (MoA 2008). One young ( $>1$ and $<2$ years of age) bull or cow is equivalent to $0.5 \mathrm{AU}$ and one calf ( $<1$ year of age) equals $0.25 \mathrm{AU}$ (MoA 2012)

\section{Determinants of Income Diversification}

Table 6 presents the association between livelihood capital, geographical location and income diversification. Regarding breeders, we found that distance to cropland and forest associated positively with income diversification, whereas education associated negatively with income diversification. Regarding feeders, we found that ownership of other livestock and of a motorbike and membership of a forest user group associated positively with income diversification. Regarding mixed breeder-feeders, we found no association between livelihood capital, geographical location and income diversification. 
Table 5 Mean comparison of total annual income, share of income sources in total income and income diversification index by farming systems (between brackets: s.e.)

\begin{tabular}{lcll}
\hline & Breeders $(n=464)$ & Feeders $(n=66)$ & Mixed breeder-feeders $(n=70)$ \\
\hline $\begin{array}{l}\text { Total annual income }(1000 \\
R p)\end{array}$ & $22,311.6(728.94)$ & $24,119.8(1879.64)$ & $21,779.2(1497.68)$ \\
Share of income source in total income $(\%)$ & & \\
Crop income & $46.2(1.41)$ & $44.2(3.67)$ & $44.6(3.76)$ \\
Cattle income & $18.0(0.87)^{\mathrm{b}}$ & $24.3(2.28)^{\mathrm{a}}$ & $19.9(2.63)^{\mathrm{ab}}$ \\
Non-farm income & $16.3(1.18)$ & $22.7(3.68)$ & $18.1(2.91)$ \\
Forest income & $9.4(0.84)^{\mathrm{a}}$ & $3.6(1.48)^{\mathrm{b}}$ & $7.5(1.84)^{\mathrm{ab}}$ \\
Paid agricultural income & $8.5(0.78)$ & $3.9(0.99)$ & $6.7(1.15)$ \\
Other livestock income & $1.3(0.20)^{\mathrm{a}}$ & $1.0(0.37)^{\mathrm{a}}$ & $2.8(1.03)^{\mathrm{b}}$ \\
Income diversification index & $2.0(0.03)$ & $2.0(0.08)$ & $2.2(0.10)$ \\
\hline
\end{tabular}

Notes: ${ }^{\mathrm{a}-\mathrm{b}}$ Means within a row with different superscripts differ significantly $(p<0.05)$ between farming systems (according to the post hoc test described in "Materials and Methods" section)

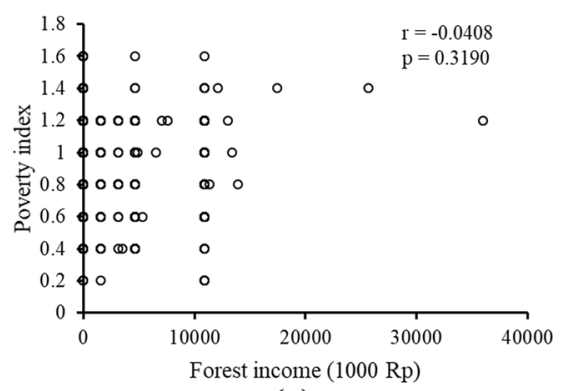

(a)

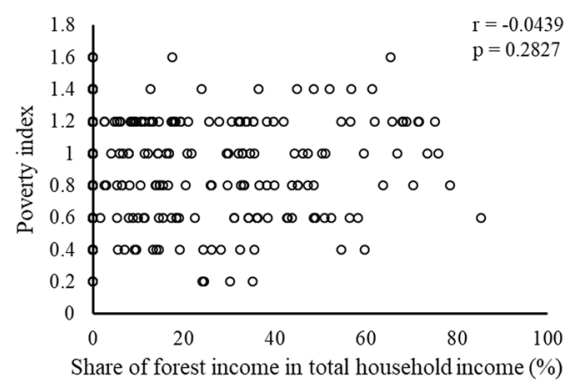

(b)

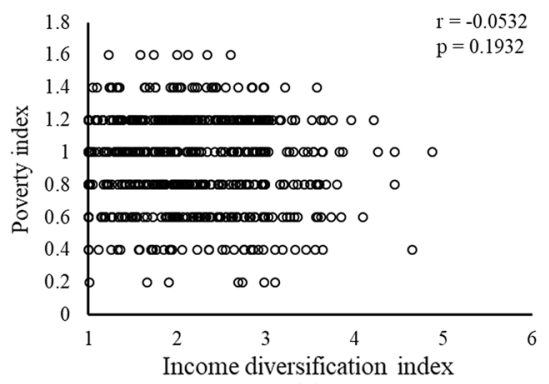

(c)

Fig. 2 Association between poverty index and forest income (a), poverty index and share of forest income in total household income (b), and poverty index and income diversification index (c). $r$ indicates the correlation, that is, strength of the association of the realizations between the variables poverty and variables forest income, share of forest income and income diversification, respectively. The symbol $\mathrm{p}$ indicates the associated $p$-values 
Table 6 Regression of income diversification on capital endowment and geographical location by farming systems (between brackets: s.e.)

\begin{tabular}{|c|c|c|c|}
\hline & Breeders & Feeders & Mixed breeder-feeders \\
\hline \multicolumn{4}{|l|}{ Human capital } \\
\hline Age (yr) & $-0.01(0.003)$ & $0.01(0.009)$ & $0.01(0.014)$ \\
\hline Education (yr) & $-0.03(0.011)^{* *}$ & $0.02(0.024)$ & $-0.01(0.041)$ \\
\hline Household size (number of persons) & $-0.04(0.026)$ & $0.05(0.072)$ & $-0.05(0.090)$ \\
\hline \multicolumn{4}{|l|}{ Natural capital } \\
\hline Farm size (ha) & $-0.01(0.149)$ & $-0.01(0.333)$ & $-0.49(0.557)$ \\
\hline \multicolumn{4}{|l|}{ Financial capital } \\
\hline Cattle herd size (AU/farm) & $0.02(0.046)$ & $-0.13(0.178)$ & $0.11(0.109)$ \\
\hline Other livestock ownership (AU/farm) & $0.13(0.107)$ & $1.29(0.496)^{* *}$ & $0.09(0.424)$ \\
\hline Having credit ${ }^{\ddagger}$ & $-0.05(0.091)$ & $0.27(0.223)$ & $0.65(0.355)$ \\
\hline Having saving account ${ }^{*}$ & $-0.12(0.082)$ & $0.08(0.196)$ & $0.16(0.275)$ \\
\hline Poverty index & $-0.13(0.115)$ & $-0.13(0.363)$ & $0.06(0.477)$ \\
\hline \multicolumn{4}{|l|}{ Physical capital } \\
\hline Having motorbike ${ }^{¥}$ & $0.14(0.140)$ & $0.81(0.384)^{* *}$ & $-0.25(0.449)$ \\
\hline \multicolumn{4}{|l|}{ Social capital } \\
\hline Membership of a forest user group ${ }^{\ddagger}$ & $0.12(0.111)$ & $0.86(0.387)^{* *}$ & $0.04(0.411)$ \\
\hline \multicolumn{4}{|l|}{ Geographical location } \\
\hline Distance to cropland (km) & $0.18(0.059)^{* * *}$ & $-0.15(0.149)$ & $0.26(0.182)$ \\
\hline Distance to forest $(\mathrm{km})$ & $0.24(0.059)^{* * *}$ & $0.11(0.153)$ & $0.20(0.275)$ \\
\hline Distance to the nearest market $(\mathrm{km})$ & $-0.03(0.015)$ & $-0.01(0.033)$ & $0.05(0.047)$ \\
\hline Constant & $2.49(0.293)^{* * *}$ & $0.63(0.902)$ & $1.69(1.156)$ \\
\hline $\mathrm{R}^{2}$ & 0.12 & 0.34 & 0.16 \\
\hline Number of observations & 464 & 66 & 70 \\
\hline
\end{tabular}

Notes: ${ }^{\ddagger}$ Dummy variable $(1=$ yes; $0=$ no)

** $/ * * *$ indicate significant difference from zero at the $5 / 1 \%$ levels, respectively

\section{Discussion}

The objective of the present paper was to understand the cattle-forest-poverty nexus, especially the roles of small-scale cattle production and harvesting forest products in the diversification of income for smallholder farmers in Indonesia. The target group for this study was farmers combining cattle farming and forest extraction. In the study area, we found that $42.8 \%$ of the farming households had this combination of activities (Table 3 ). Crop production was the most important activity at the farms, as was observed by Wardhana et al. (2017). We distinguished three different farming typologies for cattle production: mixed breeder-feeders who owned significantly more cattle than breeders, who in turn owned more cattle than feeders (Table 4). Moreover, Table 4 shows that specialized breeders and feeders were poorer (have higher poverty index) than mixed breeder-feeders, though total annual income did not differ between FSs (Table 5). Hence, breeders and feeders are probably more 
Table 7 Measurement ranges of income diversification and distances for breeders $(n=464)$

\begin{tabular}{llll}
\hline Variable & Average & Minimum & Maximum \\
\hline Income diversification index & 2.09 & 1 & 4.87 \\
Distance to cropland $(\mathrm{km})$ & 0.61 & 0 & 2.37 \\
Distance to forest $(\mathrm{km})$ & 0.39 & 0 & 3.05 \\
\hline
\end{tabular}

reluctant to take economic risk than mixed breeder-feeders as explained in the income diversification results below.

\section{Determinants of Income Diversification}

Table 6 shows that the distance to cropland and to forest is positively associated with income diversification of breeders, which is contrary to the findings of the literature outlined in Table 2. The reasons may be that farmers farther from cropland and forest may consider that there are greater opportunities for earning income from nonagricultural activities. Senadza (2014) confirmed that farmers living farther away from forests have more engagement in non-farm and self-employment compared to their counterparts living in or near the forests.

For breeders, the estimate of the partial influence of the distance to cropland is 0.18 and the estimate of the partial influence of the distance to forest is 0.24 (Table 6). For putting these estimates into perspective, the measurement range of the income diversification index needs to be considered. The income diversification index is not a count variable, but calculated according to Eq. (1) which is the standard approach followed in the literature.

The range of the income diversification among these smallholder farmers is between 1 and 4.9 with an average of 2.09, as shown in Table 7. Taking Eq. (1) into account, this means that on average a farmer has two main income sources that account for almost equal shares plus a small side activity which adds marginally so that the index exceeds 2.0 slightly. As each additional $\mathrm{km}$ of distance from cropland (forests) raises the income diversification index by $0.18(0.24)$ percentage points, it becomes obvious that both effects are indeed economically meaningful. Each additional $\mathrm{km}$ of distance from cropland (forests) raises the income diversification index by 8.6 (11.5) percentage points, that is, each additional $\mathrm{km}$ of distance increases income diversification by about one tenth.

The estimation results for breeders in Table 6 show a clear tendency of increasing diversification with increasing distance to cropland and to forests. The ranges shown in Table 7 imply that this tendency is of modest magnitude, but it is structural nevertheless. An average income diversification index of 2.09 means, for example, that a farmer has three sources of income which contribute $64 \%, 20 \%$ and $16 \%$ to the total income. Another farmer having a $11.5 \%$ higher diversification index of 2.33 will have a modestly more equally spread distribution of income sources, e.g., contributing $58 \%, 21 \%$ and $21 \%$ to total income. If the forest edges possibly retreat in the future, this effect of relying on a higher number and a more equal contribution 
of income sources will become more pronounced as more farmers will have greater distances to travel to reach forests.

This finding also appears to be plausible economically, since the collection of forest products requires capital, i.e., labour and a vehicle to transport forest products. Our results show that farmers living farther away (even if only a couple of hundred meters) from cropland and forest choose to diversify more, e.g., by following diversification strategies, such as non-farm employment that are more profitable than forest extraction.

We expected that farmers who are more market-oriented would be more educated, live farther from the forest and have less income diversification because more educated farmers are more likely to intensify and specialize. The level of education is found to be negatively associated with income diversification. Farmers having better education may rationalize their farming more than farmers with less education and, hence, take more risks, and specialization can turn into an income risk when farmgate prices of the few or single outputs considerably vary. Hence, farmers having a higher education level seem to specialize in crop production which is the best earning option in the study area as it contributes the largest share to the total household income as shown in Table 5.

Table 6 shows for feeders that ownership of other livestock and of a motorbike and membership in a forest user group are associated positively with income diversification. Hence, farmers owning a motorbike and those being member of a forest user group where they organize themselves tend to have more diverse income. However, income from other livestock and from forest contributed lower shares to total household income than income from cattle (Table 5).

Overall, our findings show that poorer households do not always diversify their income sources. This fact represents approximately $90 \%$ of farming households in the Bojonegoro region. In the present study, about $43 \%$ of the farming households combine cattle farming with forest extraction. So, the remaining $57 \%$ of the farming households do not combine cattle farming with forest extraction, presumably because their settlements and croplands are farther away from the forest and they may purchase forages for their cattle.

\section{Income Diversification Analysis}

Table 5 shows that breeders had a significantly lower monetary income from cattle and a lower cattle income share than feeders, although breeders owned significantly more cattle than feeders (Table 4 ). This is possible because breeders require approximately 2-3 years to raise a calf until it can be sold to feeders for rearing. Feeders, on the other hand, require only about 1 year to rear the steers until they can be sold to feedlots for the final fattening stage or to butchers for slaughtering. Thus, feeders have a high offtake rate which is a herd performance indicator indicating the number of animals sold divided by the number of animal present. Hence, because of the higher offtake rate for feeders than for breeders, a smaller herd can provide more annual income. In all FSs, cattle income was the second most important income source after crop farming contributing $18-24 \%$ of total household income. 
We found that breeders had a significantly higher forest income share than feeders indicating that breeders rely more on the forest for their livelihood (Table 5). However, in all FSs forest income contributed only a limited extent to total household income ranging from 3.6 to $9.4 \%$. This is somewhat lower than that in other areas in Indonesia: previous studies conducted in Sumatera and Kalimantan found that forest income from selling wild rattan, wild rubber, and wild pigs contributed 36-64\% of total household income (Widianingsih et al. 2016) as forest products collected there tend to have higher market value and farmers there tend to have a lower total income than farmers in Java.

We found that breeders and feeders had a significantly lower share of other livestock income than mixed breeder-feeders farmers (Table 5) although the ownership of other livestock did not differ significantly among FSs (Table 4). Moreover, in all FSs other livestock income contributed only a limited extent to total household income, ranging from 0.2 to $1.0 \%$. This indicates that farmers in all FSs may keep other livestock, such as chicken and ducks for home consumption rather than selling to markets.

Regarding income diversification, we found no differences among farmers (Table 5), indicating small variation of income diversification in the study area. Thus, farmers across all FSs diversified income sources according to similar strategies to achieve their livelihood outcomes, in particular, to stabilize income and to spread risks as explained in the conceptual framework (Fig. 1). Breeders, and feeders' activities at their farms are elements of their "hanging-in" strategy to maintain and protect current levels of livelihood in the face of perturbations, such as shocks, trends and seasonality as described by Dorward et al. (2009).

Although no differences were observed regarding distance to the nearest market among FSs (Table 4), feeders may have a closer personal relationship with markets because of their more frequent selling of output and higher use of traded inputs, such as concentrates, or financial resources, such as credit to buy a male calf or young bull. Thus, feeders obtain a higher offtake rate than breeders and mixed breeder-feeders. However, feeders are running higher risks than the two other FSs as, for example, if a male calf or young bull dies, they will lose substantial amounts of capital. Meanwhile, breeders obtain a lower offtake rate than feeders, but they are running less risk because they own more cattle than feeders; if a calf dies during the breeding process, breeders are still able to maintain the reproductive cow. Breeders are also less dependent on traded inputs because they usually produce their own feed or have the animals grazing in forests.

Mixed breeder-feeders are in a position to take the least risk-adverse perspective compared to breeders and feeders due to their "stepping-up" strategy by engaging in breeding and rearing at the same time to increase production and income to improve their livelihood as described by Dorward et al. (2009). If rearing is less successful, they still have the reproductive cows and vice versa. Moreover, mixed breeder-feeders have more cattle to engage in these activities, and thus are wealthier than breeders and feeders (Oosting et al. 2014). The FSs are distinct in regards to their strategies, but resemble each other in terms of their similar income diversification scores as cattle farming contributes $18-24 \%$ to total household income for all of them. 
Overall, there was no association between forest income, the share of forest income, income diversification and poverty (Fig. 2). However, we found that breeders who were poor relied more on forest resource, as was also observed by Vedeld et al. (2007). Moreover, breeders had a diversified income to meet their livelihood and forest was important for them as a source of (new) agricultural land and providing timber and NTFPs. On the other hand, feeders are more market-oriented, and less dependent on forest resources. So forests likely play a role in farms with a strategy which have insufficient resources to diversify. Nevertheless, the contribution of forest extraction to overall income is relatively small.

\section{Conclusions}

The present study shows no differences in income diversification among cattle farming systems in East Java. However, each specialized farmers' group follows their own diversification strategy on their farms. Mixed breeder-feeders are better off than breeders and feeders because they obtain higher offtake rates from rearing and breeding at the same time.

Crops are the most important source of income for farmers in all FSs, whereas cattle and forests play a role in income diversification. However, the capacity of forest extraction to support diversified farm income through agricultural land, timber and NTFPs is limited. To avoid increasing pressure on forest use, extending cattle production can be used that uses forest resources in a sustainable manner, for instances, in the form of silvopastural systems (Bussoni et al. 2015; Cubbage et al. 2012) or agroforestry (Loker 1994; van Nimwegen et al. 2009) may in the long run balance cattle expansion and, therefore, help alleviate poverty as well as contribute to forest conservation. Therefore, the Ministry of Social Affairs should promote cattle keeping as a strategy to alleviate poverty in rural areas and support the national food self-sufficiency strategy (Hamilton-Hart 2019), especially the provision of bulls for rearing targeted to the poor. This can be supplemented by the establishment of farmer groups, provision of training, and the improvement of infrastructure.

Acknowledgements The first author is thankful for the Indonesia Endowment Fund for Education (Lembaga Pengelola Dana Pendidikan/LPDP) which provided funding for this study. The work of the third author was partly funded by the EU-Project Drive4SIFood. The authors are furthermore grateful to Perhutani and the government of Bojonegoro and its livestock service agency for granting the research permit and for the helpful assistance during the survey. The authors also express their gratitude to interviewers, local hosts, local guide, and communities in the study sites for their hospitality and participation during the household survey. The authors also wish to thank two anonymous reviewers for providing constructive criticism on earlier version of this article.

Funding This study was fully funded by the Indonesia Endowment Fund for Education (Lembaga Pengelola Dana Pendidikan/LPDP) scholarship.

Data availability The data used in this study are available from the corresponding author upon reasonable request.

Code availability Not applicable. 


\section{Declarations}

Conflict of interest We certify that there is no conflict of interest with any financial organization regarding the material discussed in the manuscript.

Open Access This article is licensed under a Creative Commons Attribution 4.0 International License, which permits use, sharing, adaptation, distribution and reproduction in any medium or format, as long as you give appropriate credit to the original author(s) and the source, provide a link to the Creative Commons licence, and indicate if changes were made. The images or other third party material in this article are included in the article's Creative Commons licence, unless indicated otherwise in a credit line to the material. If material is not included in the article's Creative Commons licence and your intended use is not permitted by statutory regulation or exceeds the permitted use, you will need to obtain permission directly from the copyright holder. To view a copy of this licence, visit http://creativecommons.org/licenses/by/4.0/.

\section{References}

Abdulai A, CroleRees A (2001) Determinants of income diversification amongst rural households in Southern Mali. Food Policy 26:437-452. https://doi.org/10.1016/S0306-9192(01)00013-6

Angelsen A, Wunder S (2003) Exploring the forest-poverty link: key concepts, issues and research implications. Center for International Forestry Research, Jakarta

Ansah IGK, Gardebroek C, Ihle R (2021) Shock interactions, coping strategy choices and household food security. Clim Dev 13:414-426. https://doi.org/10.1080/17565529.2020.1785832

Babulo B, Muys B, Nega F, Tollens E, Nyssen J, Deckers J, Mathijs E (2008) Household livelihood strategies and forest dependence in the highlands of Tigray, Northern Ethiopia. Agric Syst 98:147-155. https://doi.org/10.1016/j.agsy.2008.06.001

Barrett CB, Reardon T, Webb P (2001) Nonfarm income diversification and household livelihood strategies in rural Africa: concepts, dynamics, and policy implications. Food Policy 26:315-331. https:// doi.org/10.1016/S0306-9192(01)00014-8

BPS (2016) Statistik Indonesia (Statistical Yearbook of Indonesia) 2016. Badan Pusat Statistik (BPSStatistics) Indonesia, Jakarta

BPS (2017) Statistik Indonesia (Statistical Yearbook of Indonesia) 2017. Badan Pusat Statistik (BPSStatistics Indonesia), Jakarta

BPSJ (2017) Provinsi Jawa Timur Dalam Angka 2017 (Jawa Timur Province in Figures 2017). Badan Pusat Statistik Provinsi Jawa Timur (BPS-Statistics of Jawa Timur Province), Surabaya

Bussoni A, Juan C, Fernández E, Boscana M, Cubbage F, Bentancur O (2015) Integrated beef and wood production in Uruguay: potential and limitations. Agrofor Syst 89:1107-1118. https://doi.org/10. 1007/s10457-015-9839-1

Caviglia-Harris JL, Sills EO (2005) Land use and income diversification: comparing traditional and colonist populations in the Brazilian Amazon. Agric Econ 32:221-237. https://doi.org/10.1111/j.15740862.2005.00238.x

Cubbage F et al (2012) Comparing silvopastoral systems and prospects in eight regions of the world. Agrofor Syst 86:303-314. https://doi.org/10.1007/s10457-012-9482-z

DFID (1999) DFID sustainable livelihoods guidance sheets. Department for International Development. Accessed 3 January 20192018

DJPKH (2017) Statistik Peternakan Dan Kesehatan Hewan 2017 (Livestock and Animal Health Statistics 2017). Direktorat Jenderal Peternakan dan Kesehatan Hewan Kementerian Pertanian RI, Jakarta

Dorward A et al (2009) Hanging in, stepping up and stepping out: livelihood aspirations and strategies of the poor. Dev Pract 19:240-247

Ellis F (2000) Rural livelihoods and diversity in developing countries. Oxford University Press, Oxford

Hamilton-Hart N (2019) Indonesia's quest for food self-sufficiency: a new agricultural political economy? J Contemp Asia 49:734-758. https://doi.org/10.1080/00472336.2019.1617890

Jiang H, Han L (2018) Does income diversification benefit the sustainable development of chinese listed banks? Analysis based on entropy and the Herfindahl-Hirschman Index. Entropy. https://doi.org/10. 3390/e20040255

Jiao X, Pouliot M, Walelign SZ (2017) Livelihood strategies and dynamics in rural Cambodia. World Dev 97:266-278. https://doi.org/10.1016/j.worlddev.2017.04.019 
Kassie GW (2017) The Nexus between livelihood diversification and farmland management strategies in rural Ethiopia. Cogent Econ Finan. https://doi.org/10.1080/23322039.2016.1275087

Loker WM (1994) Where's the beef?: incorporating cattle into sustainable agroforestry systems in the Amazon Basin. Agrofor Syst 25:227-241. https://doi.org/10.1007/BF00707462

Minot N, Epprecht M, Anh TTT, Trung LQ (2006) Income diversification and poverty in the Northern Uplands of Vietnam Research Report of the International Food Policy Research Institute, pp. 1-137 doi: https://doi.org/10.2499/0896291480

MoA (2008) Peraturan Menteri Pertanian no: 07/Permentan/OT.140/1/2008 Tentang Persyaratan Teknis Minimal Pemasukan Benih, Bibit Ternak dan Ternak Potong. Jakarta

MoA (2012) Peraturan Menteri Pertanian Republik Indonesia No. 82/Permentan/OT.140/12/2012 Tentang Pedoman Formasi Jabatan Fungsional Pengawas Bibit Ternak. Jakarta

MoSA (2012) Analisis data kemiskinan berdasarkan data pendataan program perlindungan sosial (PPLS) 2011. Kementerian Sosial (Ministry of Sosial Affairs of The Republic of Indonesia), Jakarta

van Nimwegen P, Lloyd DJ, Vanclay JK (2009) Prospects for integrated timber-forage-livestock agroforestry systems for economic diversification in West Timor farming communities. Canberra

Olale E, Henson S (2012) Determinants of income diversification among fishing communities in Western Kenya. Fish Res 125-126:235-242. https://doi.org/10.1016/j.fishres.2012.02.029

Oosting SJ, Udo HMJ, Viets TC (2014) Development of livestock production in the tropics: Farm and farmers' perspectives. Animal 8:1238-1248. https://doi.org/10.1017/s1751731114000548

Pellegrini L, Tasciotti L (2014) Crop diversification, dietary diversity and agricultural income: empirical evidence from eight developing countries. Can J Dev Stud Revue Canadienne D'études Du Développement 35:211-227. https://doi.org/10.1080/02255189.2014.898580

Senadza B (2014) Income diversification strategies among rural households in developing countries evidence from ghana. Afr J Econ Manag Stud 5:75-92. https://doi.org/10.1108/AJEMS-05-2012-0029

Tesfaye Y, Roos A, Campbell BM, Bohlin F (2011) Livelihood strategies and the role of forest income in participatory-managed forests of Dodola area in the bale highlands, southern Ethiopia. For Policy Econ 13:258-265. https://doi.org/10.1016/j.forpol.2011.01.002

Vedeld P, Angelsen A, Bojö J, Sjaastad E, Kobugabe Berg G (2007) Forest environmental incomes and the rural poor. Forest Policy Econ 9:869-879. https://doi.org/10.1016/j.forpol.2006.05.008

Verbeek M (2012) A guide to modern econometrics, 4th edn. Wiley, Chichester

Wardhana D, Ihle R, Heijman W (2017) Agro-clusters and rural poverty: a spatial perspective for West Java. Bull Indones Econ Stud 53:161-186. https://doi.org/10.1080/00074918.2017.1298722

Widianingsih N, Theilade I, Pouliot M (2016) Contribution of forest restoration to rural livelihoods and household income in Indonesia. Sustainability 8:835

Woldenhanna T, Oskam A (2001) Income diversification and entry barriers: evidence from the Tigray region of northern Ethiopia. Food Policy 26:351-365. https://doi.org/10.1016/S0306-9192(01) 00009-4

World Bank (2008) World Development Report 2008: Agriculture for development. Washington DC

World Bank (2018) Poverty and equity brief East Asia and Pacific: Indonesia

Publisher's Note Springer Nature remains neutral with regard to jurisdictional claims in published maps and institutional affiliations.

\section{Authors and Affiliations}

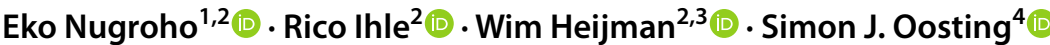

1 Department of Socio-Economy, Faculty of Animal Science, Brawijaya University, Jalan Veteran No. 1, Malang, Jawa Timur 65145, Indonesia

2 Agricultural Economics and Rural Policy Group, Department of Social Sciences, Wageningen University \& Research, Hollandseweg 1, 6706 KN Wageningen, The Netherlands

3 Department of Economics, Czech University of Life Sciences, Prague, Czech Republic

4 Animal Production Systems Group, Wageningen University \& Research, PO Box 338, 6700 AH Wageningen, The Netherlands 